\title{
Limits and possibilities for teaching and learning about breastfeeding
}

\author{
Limites e possibilidades para o ensino-aprendizagem da temática sobre aleitamento materno \\ Límites y posibilidades para la enseñanza-aprendizaje de la temática sobre lactancia materna
}

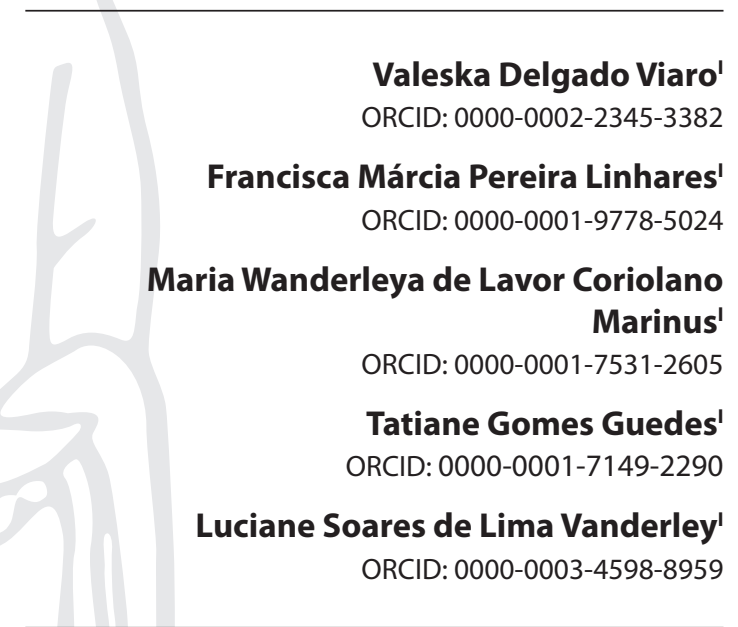

'Universidade Federal de Pernambuco. Recife, Pernambuco, Brazil.

How to cite this article: Viaro VD, Linhares FMP, Coriolano-Marinus MWL, Guedes TG, Vanderley LSL. Limits and possibilities for teaching and learning about breastfeeding. Rev Bras Enferm [Internet]. 2019;72(1):3-8.

DOI: http://dx.doi.org/10.1590/0034-7167-2018-0017

Corresponding Author:

Valeska Delgado Viaro E-mail:valeskadv@yahoo.com.br

Submission: $03-21-2018$

Approval: 06-01-2018

\begin{abstract}
Objective: To point out limits and possibilities involved in the teaching and learning process of undergraduate students from Health of a Federal Public Higher Education Institution on breastfeeding. Method: Instantaneous photography study carried out in undergraduate courses in the area of Health with professors and students involved in the teaching and learning process on breastfeeding. For data collection, the Focal Group technique was used with the students and the semi-structured interview with the professors. The speeches were submitted to the thematic content analysis of Bardin. Results: It was identified the thematic category: Limits and possibilities for the teaching and learning process on breastfeeding, from two sub-categories: Structural limitations of the courses; and Advances and obstacles in the relationship between theory and practice. Final considerations: Limits indicated as workload deficit and professorcentered teaching made progress in learning about breastfeeding difficult, and interdisciplinarity was a step forward in this process.
\end{abstract}

Descriptors: Health Personnel; Teaching; Learning; Higher Education; Breastfeeding.

\section{RESUMO}

Objetivo: Apontar limites e possibilidades envolvidos no processo de ensino-aprendizagem de graduandos da área da Saúde de uma Instituição de Ensino Superior Pública Federal sobre o tema "aleitamento materno". Método: Estudo de fotografia instantânea realizado nos cursos de graduação da área da Saúde com docentes e discentes envolvidos no processo de ensino-aprendizagem da temática sobre aleitamento materno. Para a coleta de dados foi utilizada a técnica de Grupo Focal com os discentes, e a entrevista semiestruturada com os docentes. As falas foram submetidas à análise de conteúdo temática de Bardin. Resultados: Foi identificada a categoria temática: Limites e possibilidades para o processo de ensino-aprendizagem na temática sobre aleitamento materno, a partir de duas sub-categorias: Limitações da estrutura dos cursos; e Avanços e entraves na relação entre teoria e prática. Considerações finais: Os limites apontados como déficit de carga horária e ensino centrado no docente dificultaram o progresso na aprendizagem da temática sobre aleitamento materno, sendo a interdisciplinaridade um avanço para esse processo.

Descritores: Pessoal de Saúde; Ensino; Aprendizagem; Educação Superior; Aleitamento Materno.

\section{RESUMEN}

Objetivo: Aponte límites y posibilidades involucrados en el proceso de enseñanza-aprendizaje de graduandos del área de la Salud de una Institución de Enseñanza Superior Pública Federal sobre el tema "lactancia materna". Método: Estudio de fotografía instantánea realizado en los cursos de graduación del área de la Salud con profesores y estudiante involucrados en el proceso de enseñanza-aprendizaje de la temática sobre lactancia materna. Para la recolección de datos se utilizó la técnica de Grupo Focal con los estudiantes, y la entrevista semiestructurada con los profesores. Las palabras se sometieron al análisis de contenido temático de Bardin. Resultados: Se identificó la categoría temática: Límites y posibilidades para el proceso de enseñanza-aprendizaje en la temática sobre lactancia materna, a partir de dos subcategorías: Limitaciones de la estructura de los cursos; y Avances y obstáculos en la relación entre teoría y práctica. Consideraciones finales: Los límites apuntados como déficit de carga horaria y enseñanza centrada en el profesor dificultaron el progreso en el aprendizaje de la temática sobre lactancia materna, siendo la interdisciplinaridad un avance para ese proceso. Descriptores: Personal de Salud; Educación; Aprendizaje; Educación Superior; Lactancia Materna. 


\section{INTRODUCTION}

Breast milk is the most appropriate food for children, since it prevents infant deaths when exclusively offered up to six months of life ${ }^{(1)}$; however, early weaning has still been a public health problem throughout the world ${ }^{(2)}$. In Brazil, the situation has improved but the indices of this practice are still far from the goals proposed by the WHO (World Health Organization), such as exclusive breastfeeding up to the sixth month of life of the child and supplemented up to two years of age and above ${ }^{(1)}$.

This theme has motivated researchers to study the causes of early weaning. Among the main factors that contribute to the practice of breastfeeding is the influence and support that women receive, especially from health professionals ${ }^{(3)}$.

In order to promote and support breastfeeding, it is necessary to have qualified professional training capable of dealing with the reality of the lactating mother ${ }^{(4)}$. This training has been permeated by new definitions, terms and references, stemming both from the propositions inserted in national education policies and from institutional or even individual initiatives to carry out innovations in the training process ${ }^{(5)}$.

In this sense, it is necessary to enrich the process of teaching and learning with skills and abilities that make the professional better prepared and with a broader vision for the work at work, in face of the population's health needs, especially in the promotion, protection and support to breastfeeding ${ }^{(6)}$. It is understood the teaching and learning process as a teaching process from which learning necessarily takes place, and as a challenge to be faced by university professors ${ }^{(7)}$. Students and professors actively participate in the course of the process seeking a collective construction of knowledge in order for students to achieve skills and abilities capable of meeting social needs.

In this process there must be an involvement of the student as an apprentice subject, acting in a way to transform through a creative and reflective attitude, the reality experienced by them. In this context, professors are essential professionals in the processes of change in society and are directly linked to the training of new professionals. In the international panorama, there is a growing concern about the training of higher education professors, mainly due to the increase in the number of facilities in higher education and, consequently, the increase in the number of professors ${ }^{(7)}$. Although the technical and scientific knowledge related to the profession is important, it is not enough for teaching. It is necessary to build specific knowledge directed to teaching.

In the national setting, there is concern about the number of professors and the qualification for university teaching, reflecting consequently the results of undergraduate education ${ }^{(7)}$, and the practice of the health professional in matters of public health importance such as breastfeeding. Regarding the health professionals' performance in care, the lactating mother perceives the use of authoritarianism, inconsistency of information, and difficulty in the dialogue with the lactating mother, and there is a need to modify this professional behavior so that there is support for breastfeeding ${ }^{(8)}$.

Thus, the training of the health professional should include the development of skills and competences that prepare him for interpersonal relations and the formation of links in the search to contribute to the social needs of health ${ }^{(9)}$.
At the Institution of Higher Education field of this study, undergraduate courses of the Health area develop Pedagogical Projects elaborated collectively and with didactic-pedagogical conceptions based on dialogic and problematizing strategies, reinforcing a critical, reflexive, creative and autonomous professional training ${ }^{(10)}$.

With regard to the health professional, these Pedagogical Projects should reinforce the use of methodological strategies that favor the training of workers with technical, political, ethical and human competence to act with confidence in the practice of promoting health ${ }^{(11)}$, including actions to promote, protect and support breastfeeding ${ }^{(6)}$.

Considering the relevance of breastfeeding for the reduction of infant morbidity and mortality, it is necessary that the health actions be developed from a professional training dialogic, critical and reflexive, capable of promoting the indispensable support to the lactating mother.

\section{OBJECTIVE}

To point out limits and possibilities involved in the teaching and learning process of undergraduate students from the Health area of a Federal Public Higher Education Institution on breastfeeding.

\section{METHOD}

\section{Ethical aspects}

The study followed the ethical standards for research involving human beings established by Resolution 466/2012 of the National Health Council (Conselho Nacional de Saúde). The research project was submitted to the Research Ethics Committee of the Universidade Federal de Pernambuco and approved. All participants signed the Informed Consent Term. Data collection was carried out in 2016, with the survey completed in 2017.

\section{Type of study}

In order to respond to the proposed objective, we opted for an instant photography study that consists of the description of a given situation, independent of time and space, but within a qualitative approach ${ }^{(12)}$.

\section{Study setting}

The research was carried out with professors and students of the undergraduate courses in Nursing, Speech Therapy, Medicine, Nutrition, Dentistry and Occupational Therapy, Universidade Federal de Pernambuco. The criterion for choosing these courses was to contemplate the breastfeeding in the curricular organization.

\section{Data source}

The study participants were the professors that taught about breastfeeding in the undergraduate course, these being pointed out by the coordinators of the courses; and the students were nominated by the professors interviewed, considering the period in which the issue of breastfeeding had been addressed. The 
selection of professors was for convenience and by the "snowball" method ${ }^{(12)}$, which consists of a non-probabilistic approach where the professors interviewed indicated other professors who worked in the teaching and learning process on breastfeeding.

\section{Collection and organization of data}

For the data collection with the students, the ICT was initially read and, as accepted, focal groups were conducted guided by seven questions and with an average duration of fifty minutes per meeting. The total number of students enrolled in the data collection period varied between courses, totaling 220. The six Focus Groups included 51 students. For each course there was a meeting with an average of eight participants. The number of meetings met the criterion of theoretical saturation, where the end point was the redundancy of the information/discussions in the Focus Groups ${ }^{(12)}$.

The groups were guided by the following questions: 1. How were the classes on breastfeeding held? 2. How was the content of this issue addressed?; 3. How was the participation of students in the topic of breastfeeding? 4. What are the teaching strategies used by professors?; 5 . How was the evaluation process of this theme?; 6 . How did you feel working on this theme?; 7. How do you think this theme would survive when being worked on?

For the data collection with the professors, the reading of the ICT was also performed and, after acceptance, an individual and semi-structured interview was conducted, guided by six questions with an average of thirty minutes duration for each interview. Thirteen professors participated, being three of Nursing, two of Speech Therapy, two of Medicine, three of Nutrition, two of Dentistry and one of Occupational Therapy.

The interview was guided by the following guiding questions: 1. How did classes on breastfeeding happen?; 2. How was the content of this issue addressed?; 3. How was the participation of the students in the classes where the topic about breastfeeding was approached?; 4. What teaching strategies are used? 5. How was the evaluation process of this theme?; 6 . What potential and weaknesses do you identify in addressing the issue of breastfeeding in the training process?

\section{Data analysis}

For the analysis of the speeches emerged from the interviews and the focus groups, the thematic content analysis of Bardin ${ }^{(13)}$. In the first stage, pre-analysis, transcription of interviews was performed initially in the first twenty-four hours after data collection so that expressions and other aspects were identified more accurately. Subsequently, the material was read and the documents were selected based on the research objective. The corpus was then read so that the most significant speeches were selected for the analysis of the speeches. In the second step, from the selected speeches the identification of the sense nuclei or codification, as well as the subcategories, was carried out. In the third stage, the construction of the themes is carried out and the object of study.

The speeches are identified with the initials PROF for professor and STU for student, accompanied by the term NUR for the Nursing course, MED for Medicine, NUT for Nutrition, SPEE for Speech Therapy, DENTIS for Dentistry and OT for Occupational Therapy.
From the analysis of the lines emerged two thematic subcategories: Structural limitations of the courses; and Advances and obstacles in the relationship between theory and practice. These subcategories gave rise to the category of analysis: limits and possibilities for the teaching and learning process on breastfeeding.

\section{RESULTS}

Two thematic sub-categories emerged from the participants' speeches: Structural limitations of the courses and Advances and obstacles in the relationship between theory and practice, giving rise to the category of analysis: limits and possibilities for the teaching and learning process on breastfeeding.

\section{Structural limitations of the courses}

The speeches point out that one of the limitations of the teaching and learning process on breastfeeding is permeated by problems regarding the curricular structure, where a theoretical time deficit is perceived to address the theme. The professors and students consider it to be reduced, given the complexity of the theme. In some courses the content is not contemplated in the curricular components.

...I struggled a lot to have a discipline focused only for breastfeeding
... I think even in the curriculum, even having all this methodological
approach to problematization and such, we do not teach breastfeeding
... hourly workload is one of the great fragilities... I think it's minimal.
It's not even insufficient, right? You do not approach another context.
You give brushstrokes... I make an arrangement with the puerperium
workload because the workload does not exist. (PROF NUR2)

...content is huge and the time for breastfeeding is short... (PROF SPEE 2)

...I give seminars to them of everything within the themes because it is an hour of class only... (PROF DENTIS 2)

I believe that if we want to go deeper we have to take a course, but so in the curriculum I do not think I have, I have not talked about it. (STU OT)

Another weakness pointed out by the students is related to the infrastructure of the classrooms and the high number of students. They consider that this situation does not allow the use of active methodologies, since the environment does not favor student-professor participation and interaction.

...often the very structure of the classes that we have does not favor participation. ... 70 people sitting in the amphitheater far, far, there is no opening for you to speak, for you to interact, to ask ... You will not try to go deeper. (STU MED)

The structure of the classroom, so I spoke of the professor, but it is not also her fault [incomprehensible], are huge groups. (STU MED)

I think there is the structural error as well. In the ambulatory, for example, to get her to give this lecture the day I went, it was hell, because I had 9 people and she had to serve by herself, had to teach, and to command, so we put a lot of blame on them but they have to follow a flow also of the system that... (STU MED) 


\section{Advances and obstacles in the relationship between theory and practice}

As for the relationship between theory and practice, professors and students report that the workload allocated to the practice to work on the subject is insufficient and that they need more time during the training process to perform practical classes in the settings of the Brazilian Unified Health System (Sistema Único de Saúde).

They come one day a week, on Wednesday morning to have a pediatric semiology practice ... I think it's little and it got bad... (PROF MED2)

...there should be a longer time to practice... (STU SPEE)

For me it's the fragility of the whole course ... the person does not have the opportunity to experience it in practice right now, in the population itself... That's when they do not live until they complete the internship ... things should be reversed. They should experience first and then formulate theoretical questions and consolidate knowledge... (PROF NUT 2)

... It's just to make us curious, because we do not have any practice of this here ... in serving childcare to little children, at no time was touched on breastfeeding. (STU DENTIS)

Yeah, there was nothing practical. (STU OT)

Another situation reported was the division of students into subgroups, and professor breastfeeding for all students was not addressed. The speeches show that the students did not have the same learning opportunity when they were divided into groups, being at the discretion of the professors to approach the subject or not.

Some subgroups had this class... Only it has the division of outpatient and ward, and on the day of the ward may have been the day of the person, because in Medicine there is a lot of this day, luck, professor, ward ... I just went once and then the professor paced me to the normal area of the Pediatrics practice... (STU MED)

...here is not a referral service for breastfeeding. So this ends up being moved to a small group that is the group where it has the theme ... the students of the school clinic they do not have the same knowledge and the experience of the student who does the thematic stage that goes to the hospital. (PROF SPEE1)

...last week we went to the IMIP ... and we saw the professor giving the mothers how to breastfeed, but that is not something that will happen to everyone. That was a timely issue. (STU OT)

An advance reported by the participants was the integration of disciplines and their importance to the teaching and learning process.

... with this change in the curriculum we have the collaboration of other disciplines, for example, in the Primary Care, public health professors also enter into the strategies of classes ... we can work here in a way that is truly interdisciplinary ... a professor who is in primary care, she goes there and will rescue it [which was experienced in other disciplines]. (PROF NUT1)

...they have integrated obstetrics and neonatology ... I think it's positive because we do not just approach a breastfeeding class and disagree with everything ... we also have other professors who come and go ... someone in another sector that does not address so much in this subject that does not give much importance... (PROF MED1)

Because it's such a multidisciplinary thing that you do not see everything in one chair. (STU NUT)

Concerning the interest in the subject, a controversy is observed. Professors and students of the same course (Nutrition) consider the subject to arouse interest, but others believe it does not.

This is a subject that is very neglected, like, people lack, people do not study for proof and complains, that when I fell, because I fell quite the part of breastfeeding as it was something that you think very common sense there you go, I did not study, and when it was in the test, many questions. Because they think it is something, for example, specific to a pediatrician... (STU MED)

They took the doll and looked at two little things like that and played the doll and most of them did not want to see the material ... not everyone is interested in this subject. So I noticed they were not interested. I've got frustrated. (PROF NUT1)

I think this theme instigates people. It gets very stimulated ... I think in this matter, so, it is one of the few that we can say: I learned in college. (STU NUT)

...I realize that there is a great interest in them, to work with this population or with this moment of feeding in the beginning of life... (PROF NUT3)

Another report pointed out by the students of a course was about interprofessionality when addressing breastfeeding, where it was perceived as something "erroneous", or a matter of "luck" or "bad luck", perhaps due to the lack of knowledge of the relevance of interprofessional work.

But there is the division of outpatient and ward, and on the day of the ward may have been the day of the person, because in Medicine there is a lot of it by day, by luck, by professor, by ward. (STU MED)

Then the professor ... said that she was teaching and when she went to teach, she called the nurse. Yes, this in practice. Then everyone was like, "What do you mean?" Got it? That was for her to teach what was to do and she called someone else. But the same professor in the clinic she taught, so I think it's also the luck of the person's day. (STU MED)

\section{DISCUSSION}

Quantitative and qualitative reasons are reported by participants as factors that influence the teaching and learning process. Limitations on the structure of the curriculum exemplified by a shortage of hours to address the issue of breastfeeding are 
perceived as a challenge. The incipience in the approach of the theme will reflect in the training of health professionals, leading them to inappropriate behaviors to support breastfeeding during their performance. Many health professionals are not qualified to promote and support breastfeeding, and pass on contradictory or non-contextualized information to the reality of the lactating mother ${ }^{(14)}$.

It was pointed out the limitations of the physical structure (classrooms) where part of the teaching and learning process by the participants happens as a justification for the maintenance of teaching centered on the professor's performance.

For dialogue to take place, it is necessary to live listening and speech as indispensable processes for the performance of the dialogical relationship ${ }^{(15)}$. However, the issue of infrastructure in a teaching unit may not be sufficient reason to justify a nondialogic approach and use of participatory strategies in the teaching and learning process, with traditional methods, passive, professor-focused and content information. It is necessary that this educator, as transforming agent, encourages and stimulates the students to the construction of knowledge ${ }^{(16)}$.

Regardless of the physical structure where the teaching and learning process takes place, the professor should have the ability to keep the students involved and participating in a collective construction. To this end, it is necessary time and professional improvement through the implantation of training and work management models. Those who achieve this goal usually provide students with satisfactory teaching ${ }^{(17)}$. However, the physical structure can be considered relevant in the definition of educational outcomes ${ }^{(18)}$.

The articulation between theory and practice was punctuated by the study participants as a fragility, where some groups of students were not contemplated with the subject in the practical classes. This articulation must be well established so that the construction of knowledge does not occur in a fragmented way ${ }^{(5)}$. It is believed that practice needs theory as well as accurate theory of practice. The theoretical basis will base the practice, and this is fundamental in the construction of knowledge, besides being a potentiating element for the development of academic training ${ }^{(19-21)}$. The relation between theory and practice does not necessarily presuppose a sort of first class theoretical class and then the practical class, it is desirable even that this order be subverted so that the student has the opportunity to identify the problems encountered in the lactating mother care, and from these build the theoretical foundation able to meet the needs of lactating mother.

Another aspect related to the relationship between theory and practice is the students'lack of interest in the breastfeeding. The students of a course understand that the subject should be directed to some specialties (Pediatrics), disregarding the relevance of the theme to future professional practice. In another course the disinterest was also reported, however, with the aggravating factor that the subject on breastfeeding is considered structuring in this referred course, graduation in Nutrition. Educational practice may not be motivating students to build knowledge despite the relevance of the theme to training ${ }^{(22)}$.

Another situation considered as an obstacle in the teaching and learning process on breastfeeding identified in the reports of the students of a course was interprofessionality. This fact may be related to the difficulty of some professionals to share their practices with other health workers ${ }^{(23)}$. The lack of knowledge about the importance of interprofessional experience during training, in compliance with the principle of comprehensiveness in care, coupled with a possible corporatism of the professions, does not favor the planning by the professors of opportunities of interprofessional experiences in subjects typically interdisciplinary, such as breastfeeding.

Regarding the integration of disciplines in breastfeeding, this was considered an advance by the students of some courses, in particular Nursing course, for the construction of knowledge, since interdisciplinarity promotes spaces that increase the understanding and the knowledge of the professional reality ${ }^{(7)}$.

This fact of positivity also occurred with the students of a School of Health Sciences, in Brasilia, who works with the integrated and flexible curriculum in the institution ${ }^{(23)}$. Fragmented teaching by areas may make it difficult to contribute knowledge to social problems, where interdisciplinarity would be an alternative to this fragmentation ${ }^{(7)}$.

This progress reported by the participants regarding interdisciplinarity occurs through the contribution of these fragmented processes to the complexity of higher education, facilitating the reading of a reality and consequently of the interventions.

\section{Study limitations}

Certain limitations identified in the course of the study made difficult some phases of the research, such as the refusal of participation of a group of students who lived the topic; the explicit non-contemplation of breastfeeding issue in the curriculum of most courses; and the possibility that the professor was not the professor of the students interviewed in the subject matter, and could justify some dissent identified during the study.

\section{Contributions to the sectors of Nursing, Health or Public Policy}

Regarding the research's contributions, it is expected that a solid professional training in Health graduation in the subject on breastfeeding, based on a teaching and learning process contemplated by strategies that allow the active participation of the student, be able to train health professionals with the necessary skills and abilities to generate changes in the breastfeeding promotion actions, thus approaching the biopsychosocial needs of lactating mothers.

\section{FINAL CONSIDERATIONS}

Based on the reports of the students and professors interviewed, it was identified that the limits pointed out during the teaching and learning process such as workload deficit and professorcentered teaching make it difficult to progress in learning about breastfeeding, with interdisciplinarity being a step forward for this process. It is the responsibility of professors and students to act in a teaching process based on the reality of the different settings of the Brazilian Unified Health System, approaching theory and practice, considering the context of lactating mothers and acting interprofessional in face of a complex theme such as breastfeeding. 


\section{REFERENCES}

1. Ministério da Saúde (BR). Amamentação [Internet]. Brasília (DF): Ministério da Saúde; 2012 [cited 2013 Sep 11]. Available from: http://www. brasil.gov.br/sobre/saude/maternidade/pos-parto

2. Santos PRM, Neves RCF. Causas mais comum do desmame precoce: revisão integrativa da literatura. Rev Eletr Educ Ciênc [Internet]. 2012 [cited 2013 Sep 18];2(3):12-8. Available from: http://www.fira.edu.br/revista/reec_vol2_num2_pag12.pdf

3. Marques ES, Cotta RMM, Magalhães KA, Sant'Ana LFR, Gomes AP, Siqueira-Batista R. [The influence of the social net of lactating mothers in the breastfeeding: the strategic role of the relatives and professionals of health]. Ciênc Saúde Colet [Internet]. 2010 [cited 2013 Mar 30];15(Supl 1):1391-1400. Available from: http://dx.doi.org/10.1590/S1413-81232010000700049 Portuguese.

4. Lundberg PC, Ngoc TTT. Breast-feeding attitudes and practices among Vietnamese mothers in Ho Chi Minh City. Midwifery. 2012;28(2):2527. doi: 10.1016/j.midw.2011.02.012

5. Anjos KF, Santos VC, Almeida OS, Boery RNSO, Boery EN. [Perception of nursing graduates about methodologies and strategies for teachinglearning]. Rev Enferm UFPE Online [Internet]. 2013 [cited 2013 Feb 02];7(8):5120-8. Available from: https://doi.org/10.5205/1981-8963v7i8a11783p5120-5128-2013 Portuguese.

6. Badagnan HF, Oliveira HS, Monteiro JCS, Gomes FA, Nakano AMS. Knowledge of students in a nursing course about breastfeeding. Acta Paul Enferm [Internet]. 2012 [cited 2014 Dec 19];25(5):708-12. Available from: http://www.scielo.br/pdf/ape/v25n5/en_10.pdf

7. Pimenta SG, Anastasiou LGC. Docência no ensino superior. São Paulo (SP): Cortez, 2014. 280 p.

8. Spencer A, Jones L. Understanding breast-feeding: how to offer practical help. Curr Paediatr [Internet]. 2002 [cited 2015 May 14];12(2):93-7. Available from: https://doi.org/10.1054/cupe.2001.0258

9. Gonze GG, Silva GA. A integralidade na formação dos profissionais da saúde: tecendo valores. Physis [Internet]. 2011 [cited 2016 Apr 2];21(1):129-46. Available from: http://dx.doi.org/10.1590/S0103-73312011000100008 [Portuguese]

10. Universidade Federal de Pernambuco. Pró-Reitoria para Assuntos Acadêmicos [Internet]. Recife (PE): UFPE; 2014 [cited 2015 Feb 02] Available from: https://www.ufpe.br/web/guest/inicio

11. Frenk J, Chen L, Bhutta ZA, Cohen J, Crisp N, Evans T, et al. Health professionals for a new century: transforming education to strengthen health systems in an interdependent world. Lancet [Internet]. 2010 [cited 2017 May 30];376(9756):1923-58. Available from: doi:https://doi. org/10.1016/S0140-6736(10)61854-5

12. Flick U. Desenho da pesquisa qualitativa. Porto Alegre (RS): Artmed; 2009. 248 p.

13. Bardin L. Análise de conteúdo. 7 ed. São Paulo (SP): Edições 70; 2011. 96 p.

14. Almeida JM, Luz SAB. Support of breastfeeding by health professionals: integrative review of the literature. Rev Paul Pediatr [Internet]. 2015 [cited 2018 Oct 28];33(3):355-362. Available from: http://dx.doi.org/10.1016/j.rpped.2014.10.002

15. Freire P. Pedagogia do oprimido. 50. ed. São Paulo (SP): Paz e Terra; 2011. 256 p.

16. Freire P. Política e educação. São Paulo (SP): Paz e Terra; 2014. 57 p.

17. 17.Backes VMS, Moya JLM. Expressions of pedagogical content knowledge of an experience nursing teacher Texto Contexto Enferm [Internet]. 2013 [cited 2018 Oct 28];22(3):804-10. Available from: http://dx.doi.org/10.1590/S0104-07072013000300029

18. Soares Neto JJ, Jesus GR, Karino CA, Andrade DF. Uma escala para medir a infraestrutura escolar. Est Aval Educ [Internet]. 2013 [cited 2017 Apr 4];24(54):78-99. Available from: http://publicacoes.fcc.org.br/ojs/index.php/eae/article/view/1903/1887

19. Mann K, Gordon EJ, MacLeod EA. Reflection and reflective practice in health professions education: a systematic review. Adv in Health Sci Educ [Internet]. 2009 [cited 2017 Jan 12];14(4):595. Available from: https://doi.org/10.1007/s10459-007-9090-2

20. Pitkajarvi M, Eriksson E, Pitkala K. Culturally diverse health care students' experiences with teaching strategies in Finland: a national survey. Nurse Educ Today [Internet]. 2013 [cited 2017 Jan 12];33(6):590-5. Available from: https://doi.org/10.1016/j.nedt.2012.07.004

21. McLaughlin JE, Roth MT, Glatt DM, Gharkholonarehe N, Davidson CA, Griffin LM, et al. The flipped classroom: a course redesign to foster learning and engagement in a health professions school. Acad Med. 2014;89(2):236-43. doi: 10.1097/ACM.0000000000000086

22. Rios IC, Schraiber LB. Humanização e humanidades em medicina. São Paulo (SP): Unesp; 2012. 296 p.

23. Melo BC, Sant'Ana G. A prática da metodologia ativa: compreensão dos discentes enquanto autores do processo ensino- aprendizagem. Com Ciências Saúde [Internet]. 2012 [cited 2014 Dec 20]:23(4):327-39. Available from: http://bvsms.saude.gov.br/bvs/artigos/pratica_ metodologia_ativa.pdf 